\title{
Mini-metodevurdering: Rask og trygg innføring av nye metoder i sykehus
}

\author{
Brynjar Fure, Sari Susanna Ormstad, Vidar Jusnes Vang, Vigdis Lauvrak, \\ Katrine Bjørnebek Frønsdal, Åse Skår og Helene Arentz-Hansen \\ Seksjon for spesialisthelsetjenesten, Nasjonalt kunnskapssenter for helsetjenesten \\ Korrespondanse: Brynjar Fure, Seksjon for spesialisthelsetjenesten, Nasjonalt kunnskapssenter for helsetjenesten \\ E-post: brynjar.fure@kunnskapssenteret.no Telefon: 45426388
}

\begin{abstract}
SAMMENDRAG
Helsemyndigheter, helseledere og mange klinikere har lenge sett behovet for en mer systematisk vurdering av nytten ved nye metoder som vurderes innført i norske sykehus. Selv om en ny metode kan fremstå som nyttig, viser det seg $\mathrm{i}$ en del tilfeller at metoden ikke lever opp til forventningene når den tas i bruk i klinisk praksis. Pasienter i den norske helsetjenesten har krav på behandling som er effektiv og sikker, og skal ikke bli utsatt for ikke-etablert behandling uten at de selv er klar over det.

Helse- og omsorgsdepartementet innfører i 2013 et nytt system for vurdering av nye metoder i helsetjenesten. Basis i dette systemet er instrumentet "Mini-metodevurdering", som skal utføres lokalt i helseforetakene når en ny metode vurderes innført.

Mini-metodevurdering omfatter litteratursøk og kritisk vurdering av forskningslitteratur om metoden, med hovedvekt på effekt og sikkerhet. I tillegg vurderes organisatoriske, økonomiske og etiske konsekvenser av å innføre metoden. Hoveddelen i en mini-metodevurdering utføres av en kliniker eller leder som ønsker å innføre en ny metode. Gjennomføring av en mini-metodevurdering tar vanligvis ca. en uke. Ferdigstilte mini-metodevurderinger publiseres via en nasjonal nettside - www.minimetodevurdering.no. Metoder som skal vurderes er prosedyrerelatert diagnostikk og behandling, medisinsk utstyr og organisatoriske tiltak. Det er utarbeidet kriterier for når det er nødvendig eller eventuelt ikke nødvendig å utføre en mini-metodevurdering.

En mini-metodevurdering er ikke en beslutning i seg selv, men snarere en kunnskapsbasert beslutningsstøtte for sykehusets ledelse før det fattes vedtak om eventuell innføring av en ny metode.
\end{abstract}

Fure B, Ormstad SS, Vang VS, Lauvrak V, Frønsdal KB, Skår A, Arentz-Hansen H. Mini-Health Technology Assessment: Rapid and safe introduction of new health technologies in hospitals. Nor J Epidemiol 2013; 23 (2): 171-175.

\section{ENGLISH SUMMARY}

Health authorities, hospital leaders and many clinicians have long recognized the need for a more systematic evaluation before introducing new health technologies in Norwegian hospitals. A new technology that appears to be beneficial does not always live up to its expectations when it is introduced in clinical practice. Patients are entitled to treatments that are effective and safe, and should not be subject to nonestablished treatments without being aware of it.

In 2013, Norwegian health authorities have established a new system for evaluating new health technologies in hospitals. The basis of this system is a check-list referred to as mini-Health Technology Assessment (mini-HTA) performed locally in hospitals when a new technology is under consideration for implementation.

Mini-HTA comprises a literature search and critical appraisal of research literature regarding the effectiveness and safety of the new technology. In addition, organizational, economic and ethical consequences of the new technology are evaluated. The main part of a mini-HTA is performed by the clinician or leader who wants to introduce the new technology. Completion of a mini-HTA usually takes approximately one week. Completed mini-HTA forms are published on a national website - www.minimetodevurdering.no. Mini-HTA is relevant for technologies that involve diagnostic and therapeutic procedures, medical devices and organizational changes. Criteria have been developed for when a mini-HTA should and should not be performed in Norwegian hospitals.

Mini-HTA is not a decision in itself, but rather an evidence-based decision support tool that hospital leaders may use before making decisions regarding the introduction of new health technologies.

This is an open access article distributed under the Creative Commons Attribution Licence, which permits unrestricted use, distribution, and reproduction in any medium, provided the original work is properly cited. 


\section{BAKGRUNN}

Innføring av nye metoder i helsetjenesten finner ofte sted etter at leger og andre klinikere i helsetjenesten har fått høre om en ny metode ved et møte eller en kongress i Norge eller utlandet. Entusiastiske ildsjeler spiller i mange tilfeller en avgjørende rolle ved innføring av nye metoder, både i sykehus og andre deler av helsetjenesten, ofte begrunnet $i$ ønsket om at også de norske pasientene bør få tilgang til nye metoder så raskt som mulig. I tillegg finnes det andre aktører, som for eksempel pasientgrupper og produsenter av legemidler og medisinsk utstyr som ønsker en rask innføring av nye metoder. En utfordring ved en slik "begeistringsstyrt" innføring av nye tiltak, er at den vitenskapelige dokumentasjonen ikke alltid er tilstrekkelig belyst på forhånd. Det kan likevel vise seg at det var riktig å innføre metoden i helsetjenesten, men mange klinikere har erfart at nye metoder ikke alltid viser seg å være like nyttige som det en først fikk inntrykk av. Det er enighet om at pasienter i norske sykehus har krav på behandling som er effektiv, men mange vil mene at sikkerheten ved en metode er minst like viktig.

I den kliniske hverdagen kan det være utfordrende å få oversikt over forskningsdokumentasjonen for et nytt tiltak, selv for klinikere med forskningserfaring. Det produseres stadig mer forskning, og ved litteratursøk etter primærstudier på PubMed er det ikke uvanlig å sitte igjen med hundre- eller tusenvis av treff. For den enkelte lege, sykepleier eller terapeut kan det være vanskelig å vite om en faktisk har identifisert alle aktuelle studier om det nye tiltaket, og ikke minst å vurdere hvilke resultater en kan stole på. Hovedhensikten med all medisinsk og helsefaglig forskning er i siste instans at den skal bidra til et bedre tilbud til pasientene. Spørsmålet er hvordan de relevante resultatene kan trekkes ut av forskningslitteraturen og omsettes til fornuftige tiltak i klinisk praksis.

I den enkelte avdeling eller klinikk på sykehuset kan nye metoder ha organisatoriske konsekvenser som ikke alltid er umiddelbart overskuelige. Nye tiltak kan for eksempel kreve nye lokaler eller omorganisering av vaktfunksjoner. Som regel vil det være nødvendig med opplæring i den nye metoden. Selv om en metode er både effektiv og sikker i bruk, må den kunne innføres innenfor sykehusets økonomiske rammer. Et sentralt spørsmål for enhver leder i sykehusene vil være hva det nye tiltaket koster. Har sykehuset råd til å innføre tiltaket? Det kan også være fornuftig å tenke gjennom om en ny metode utfordrer samfunnets etiske verdigrunnlag før metoden tas i bruk. Dette kan for eksempel gjelde tiltak i livets siste fase eller innen fostermedisin.

For å møte denne utfordringen ble "Mini-metodevurdering" innført i Norge i 2012, som et beslutningsstøtteverktøy for ledere $\mathrm{i}$ spesialisthelsetjenesten når nye metoder vurderes innført i sykehusene. Verktøyet vektlegger systematisk innhenting av forskningsdokumentasjon vedrørende effekt og sikkerhet av det nye tiltaket, i tillegg til vurdering av kostnader samt etiske og organisatoriske konsekvenser forbundet med innføring i sykehusene. Forut for lansering av det nye systemet for mini-metodevurderinger i norske sykehus, har det vært en bred prosess hvor de regionale helseforetakene, Nasjonalt kunnskapssenter for helsetjenesten (Kunnskapssenteret), Helsedirektoratet og Helse- og omsorgsdepartementet har bidratt. Mini-metodevurdering utgjør en viktig del av et mer omfattende system for vurdering av nye metoder $\mathrm{i}$ helsetjenesten som implementeres i 2013. Kunnskapssenteret har tidligere publisert to rapporter om henholdsvis systemer for mini-metodevurderinger i andre land (1) og om et pilotprosjekt om mini-metodevurderinger i Helse Vest (2).

\section{HVA ER MINI-METODEVURDERING?}

Mini-metodevurdering eller mini-HTA (mini-Health Technology Assessment) er en sjekkliste i form av et skjema i tre deler som skal utfylles lokalt i sykehuset når en ny metode vurderes innført. En metode klassifiseres i denne sammenhengen som ny når den ikke har vært i rutinemessig bruk i Norge, når den kun har vært brukt på et svært begrenset antall pasienter eller når den innebærer en ny anvendelse av en eksisterende metode, for eksempel endret indikasjonsgrunnlag (3). Mini-metodevurdering benyttes for metoder som involverer prosedyrerelatert behandling eller diagnostikk, medisinsk utstyr eller organisatoriske endringer. Legemidler og metoder som innebærer screening eller høyspesialisert helsehjelp skal derimot ikke omfattes av mini-metodevurderinger, da disse vurderes på nasjonalt nivå i mer omfattende metodevurderinger (4). Det samme gjelder for metodevurderinger med helseøkonomiske analyser.

\section{Del 1 - vurdering av metoden}

Del 1 av mini-metodevurderingsskjemaet fylles ut av forslagsstilleren. Forslagsstiller kan være en kliniker eller leder ved et sykehus som ønsker å innføre en ny metode ved sykehuset. Basert på erfaringer fra pilotprosjektet om mini-metodevurderinger i Helse Vest (2) tar utfylling av del 1, som utgjør hoveddelen av en mini-metodevurderingen, ca. en uke. Her gjør forslagsstilleren rede for den aktuelle metoden, pasientgrunnlaget og kunnskapsgrunnlaget for den nye metoden. I tillegg vurderes økonomiske, organisatoriske og etiske konsekvenser ved innføring av metoden.

Mini-metodevurdering:

- Er et beslutningsverkt $\varnothing y$ for ledere lokalt i helseforetakene

- Benyttes for å innhente kunnskapsgrunnlag om effekt og sikkerhet av en ny metode, samt vurdere $\emptyset$ konomiske, organisatoriske og etiske konsekvenser av metoden

- Gjennomføres av helsepersonell eller ledere i løpet av ca. en uke med hjelp fra bibliotekar og $\varnothing$ konom

- Publiseres på www.mini.metodevurdering.no når skjemaet er ferdig utfylt

Figur 1. Faktaboks om mini-metodevurdering. 
Kunnskapsgrunnlaget vedrørende effekt og sikkerhet av den nye metoden skal fortrinnsvis basere seg på oppsummert forskning. Søk etter oppsummert forskning om den nye metoden utføres i den norske nasjonale databasen for nye metoder, MedNytt (5) og i andre databaser for oppsummert forskning. For nye metoder vil det imidlertid i mange tilfeller ikke foreligge oppsummert forskning, og det vil da være nødvendig å søke etter primærstudier. Litteratursøket kan med fordel utføres av sykehusets bibliotekar. Bibliotekarene i norske sykehus har spesialkompetanse på systematiske litteratursøk, og mange av dem har gjennomgått spesiell opplæring i identifisering av forskningslitteratur.

I denne sammenheng omfatter kunnskapsgrunnlaget først og fremst klinisk effekt og sikkerhet ved den nye metoden basert på data fra forskningsstudier eller pasientregistre. Effektestimatene for metoden trekkes ut av studier eller registerdata, og settes i tabeller, for eksempel som relativ risiko, odds ratio eller prosentandeler. Den som fyller ut skjemaet skal også vurdere kvaliteten av forskningsdokumentasjonen, både når denne foreligger som primærstudier og oppsummert $\mathrm{i}$ systematiske oversikter. I HTA-organisasjoner brukes vanligvis internasjonalt validerte instrumenter for å vurdere kvaliteten på forskningsgrunnlaget for en metode, for eksempel GRADE-instrumentet (6). Ved gjennomføring av mini-metodevurdering er det ikke realistisk å utføre kvalitetsvurdering ved hjelp av GRADE, både fordi dette vil kreve betydelig opplæring og fordi prosessen vil bli for ressurskrevende. Imidlertid er flere av de sentrale spørsmålene fra GRADE lagt inn i mini-metodevurderingsskjemaet. Forslagsstilleren blir bedt om svare på om resultatene i studiene som undersøker effekt og sikkerhet av et tiltak peker i samme retning, og om pasientene som er undersøkt i studiene er representative for de pasientene som skal få tilbud om metoden i klinisk praksis. I tillegg må det tas stilling til om det best egnede studiedesignet er benyttet for å kunne gi svar på det aktuelle forskningsspørsmålet. Ved spørsmål om effekt av et tiltak er det ønskelig med data fra randomiserte kontrollerte studier. I en del tilfeller vil det imidlertid ikke foreligge slike data, for eksempel fordi det ikke alltid er praktisk mulig eller etisk forsvarlig å gjennomføre randomiserte forsøk. I slike tilfeller er det aktuelt å bruke data fra andre typer kilder, for eksempel pasientserier eller pasientregistre, for å belyse metodens effekt og sikkerhet.

Økonomidelen av mini-metodevurderingsskjemaet bør fylles ut i samarbeid med sykehusets økonomiavdeling. Selv om skjemaet etterspør data fra helseøkonomiske studier utført i Norge eller utlandet, er hovedfokus rettet mot sykehusets egen økonomi. I denne delen oppgis hvilke utgifter og inntekter den nye metoden forventes å medføre for foretaket lokalt.

Mange sykehus har allerede gode systemer for å ivareta organisatoriske konsekvenser ved innføring av nye metoder. Mini-metodevurderingsskjemaet kan likevel være en hjelp til å få oversikt over konsekvenser som behov for kompetanseheving, endring av vaktfunksjoner, bemanning, endring av pasientstrømmer eller endret samhandling med førstelinjetjenesten.

Mini-metodevurderingsskjemaet inneholder ett spørsmål om hvorvidt den nye metoden er etisk utfordrende. Dette kan dreie seg om metoden har betydning for rettferdighet i samfunnet, selvbestemmelse eller religiøse verdier.

\section{Del 2 -fagfellevurdering}

Del 2 av mini-metodevurderingen er en fagfellevurdering utført av en person som har inngående kjennskap til fagområdet, men som ikke er direkte involvert i innføringen av den nye metoden. Dette kan for eksempel være en fagperson som jobber ved et annet sykehus, gjerne $i$ en annen helseregion. I denne delen av skjemaet skal fagfellen vurdere om mini-metodevurderingen er tilfredsstillende gjennomført, blant annet om litteratursøk er utført på en god måte og om alle relevante studier er tatt med i vurderingen. Både del 1 av skjemaet, som fylles ut av forslagsstiller, og del 2, som fylles ut av fagfelle, inneholder en habilitetserklæring.

\section{Del 3 - innstilling til beslutning}

Del 3 av mini-metodevurderingsskjemaet fylles ut av beslutningstaker eller den medarbeider som forbereder saken for beslutning i helseforetaket. I denne delen skal beslutningstaker vurdere om kunnskapsgrunnlaget og konsekvenser av en eventuell innføring av den nye metoden er tilstrekkelig belyst. Del 3 av mini-metodevurderingsskjemaet er ikke en beslutning per se, men snarere en støtte til å kunne fatte en kunnskapsbasert beslutning. Selv ved positivt utfall av en mini-metodevurderingprosess kan det være gode grunner til at metoden likevel ikke innføres i sykehuset, for eksempel sykehusets overordnede strategi.

\section{Publisering AV Ferdigstilte MINI- METODEVURDERINGER}

Ferdigstilte mini-metodevurderinger (del 1 og 2) publiseres $\mathrm{i}$ den nasjonale databasen for mini-metodevurderinger (7). Selv om mini-metodevurderinger i prinsippet er utarbeidet for lokal bruk i ett helseforetak, oppfordres det sterkt til å publisere disse i den nasjonale databasen, dels for å unngå dobbeltarbeid og dels for å sikre transparens og dermed etterprøvbarhet av vurderingene. I databasen for mini-metodevurderinger ligger blant annet tomme skjemaer og en kortfattet veileder som beskriver i hvilke tilfeller det er aktuelt å utføre mini-metodevurderinger (7). Den nasjonale databasen for mini-metodevurderinger driftes av Kunnskapssenteret.

\section{NÅR SKAL DET UTFØRES MINI- METODEVURDERING?}

Det er neppe rasjonelt å utføre mini-metodevurdering for absolutt alle metoder som vurderes innført i sy- 
kehusene. Mini-metodevurdering skal i utgangspunktet utføres når det foreligger klinisk relevant usikkerhet eller faglig uenighet vedrørende kunnskapsgrunnlaget for en metode, eller når innføring av metoden reiser etiske spørsmål. I noen tilfeller er det åpenbart at en metode allerede er etablert i helsetjenesten, for eksempel ved andre sykehus i landet. Når metodens kliniske effekt og sikkerhet er klarlagt tidligere, er det ikke hensiktsmessig å utføre en mini-metodevurdering. Motsatt er det heller ikke nødvendig å utføre en minimetodevurdering dersom det er åpenbart at kunnskapsgrunnlaget for metoden er mangelfullt. Det kan likevel være nyttig å utarbeide en mini-metodevurdering nettopp for å avklare hvor godt kunnskapsgrunnlaget er.

\section{Hvordan bruke resultatet fra en mini- metodevurdering?}

Når en mini-metodevurdering konkluderer med at kunnskapsgrunnlaget, samt organisatoriske, økonomiske og etiske konsekvenser ved en metode er akseptable, kan metoden innføres innenfor foretakets økonomiske rammer.

Mini-metodevurderinger utgjør en del av et større system for innføring av nye metoder i spesialisthelsetjenesten. Dersom det etter en gjennomført minimetodevurdering fortsatt er uenighet eller usikkerhet knyttet til kunnskapsgrunnlaget, kan problemstillingen løftes fra lokalt til regionalt eller nasjonalt nivå for en bredere vurdering. Andre mulige utganger av en minimetodevurdering er at spørsmålet overføres til forskningslovgivningen, slik at pasientene får tilgang til den nye metoden innenfor en forskningsstudie, eller at metoden ikke innføres. Når en mini-metodevurdering avdekker behov for vurdering av etiske konsekvenser av allmenn interesse for samfunnet eller for helseøkonomiske analyser av metoden, utføres en nasjonal metodevurdering. I tillegg skal en metodevurdering også utføres nasjonalt når eventuell innføring av en ny metode kan komme i konflikt med prinsippet om et likeverdig helsetjenestetilbud over hele landet (7).

\section{Utfordringer ved mini-metodevurderinger}

En viktig forutsetning for at det nye systemet for minimetodevurderinger skal lykkes, er at foretakene har tilgang til tilstrekkelige fagressurser i bibliotekartjenesten og økonomiavdelingen. Dette kan være en utfordring i små sykehus. De regionale helseforetakene vil opprette ressursgrupper som kan hjelpe helseforetakene med å utføre mini-metodevurderinger. Kunnskapssenteret har i samarbeid med Helse Vest RHF opprettet en nasjonal ressursgruppe med spesialkompetanse innen litteratursøk, kritisk vurdering av forskningslitteratur og vurdering av økonomiske konsekvenser ved nye metoder. Denne ressursgruppen kan bidra med støtte, både til regionale og lokale helseforetak.

Både klinikere og ledere i sykehus kan oppleve at mini-metodevurdering stjeler ressurser fra den kliniske virksomheten og innebærer økt byråkratisering. Mot- argumentet er likevel at noen dagers jobbing med en mini-metodevurdering kan bidra til å sikre at norske pasienter får behandling som er effektiv og sikker. En annen hensikt med mini-metodevurderinger er å motvirke at pasientene utsettes for ikke-etablert behandling uten at de selv er klar over det.

Mini-metodevurderinger vil i noen tilfeller utfordre klinikernes opplevelse av faglig autonomi, ettersom systemet legger opp til åpne prosesser hvor en kritisk gjennomgang av forskningsgrunnlaget legges til grunn for beslutning om eventuell innføring av en ny metode i sykehuset. Metoder som mangler tilstrekkelig dokumentasjon vil dermed, som hovedregel, ikke bli innført i rutinemessig bruk i sykehusene. Dette kan av noen oppleves som en unødvendig styring fra myndighetens side. På den annen side vil også en mini-metodevurdering kunne innebære at gode og nyttige metoder kommer raskere ut i klinisk praksis.

Ved kartleggingen av mini-metodevurderingssystemer $\mathrm{i}$ verden fremkom det klart at forankring i sykehusledelsen er helt avgjørende for å lykkes med å innføre mini-metodevurderinger som støtte til kunnskapsbaserte beslutninger i sykehusene (1). Dette betyr i praksis at sykehusledelsen aktivt må etterspørre og stille krav om at mini-metodevurdering skal være utført før det tas stilling til om en ny metode skal innføres. I Norge er implementeringen av mini-metodevurderingssystemet lagt til lederlinjen i helsetjenesten.

\section{INTERNASJONALE ERFARINGER MED MINI- METODEVURDERING}

Kunnskapssenteret har identifisert i alt åtte minimetodevurderingssystemer fra seks forskjellige land $\mathrm{i}$ verden (1). Det norske skjemaet for mini-metodevurdering bygger $\mathrm{i}$ stor grad på det som benyttes $\mathrm{i}$ Danmark. Mini-metodevurderinger er også et av satsningsområdene $\mathrm{i}$ det europeiske forskningsprosjektet "Adopting Hospital-based Health Technology Assessment in EU" (AdHopHTA) (8), som Kunnskapssenteret deltar i. Dette prosjektet pågår i perioden 20132015, og tar sikte på å kartlegge og evaluere forskjellige systemer for metodevurderinger utført på sykehusnivå i Europa. Resultatet av AdHopHTA vil være en slags verktøykasse for gjennomføring av metodevurderinger på sykehusnivå.

\section{KONKLUSJON}

Mini-metodevurderinger bidrar til å omsette forskningsresultater om en ny metode til klinisk praksis, og benyttes som et beslutningsstøtteverktøy lokalt i helseforetakene når en ny metode vurderes innført. Det tar i de fleste tilfeller ca. en uke å gjennomføre en mini-metodevurdering. Dette innbefatter innhenting av data for klinisk effekt og sikkerhet, samt vurdering av økonomiske, organisatoriske og etiske konsekvenser av å innføre den nye metoden. Ferdigstilte minimetodevurderinger publiseres åpent $\mathrm{i}$ den nasjonale databasen for mini-metodevurderinger. 


\section{REFERANSER}

1. Ormstad SS, Graff BA, Norderhaug IN. Kartlegging og drøfting av ulike mini-HTA-systemer internasjonalt. Rapport fra Kunnskapssenteret nr 01-2010. Oslo: Nasjonalt kunnskapssenter for helsetjenesten, 2010.

2. Arentz-Hansen H, Ormstad SS, Hamidi V, Juvet LK, Fure B, Norderhaug IN. Utprøving av mini-HTA i Helse Vest RHF. Notat. Oslo: Nasjonalt kunnskapssenter for helsetjenesten, 2011.

3. Johansen MS, Norderhaug I. Nye og kostnadskrevende metoder. Forslag til system for håndtering av ny teknologi i helsetjenesten. Rapport IS - 13/2009. Oslo: Helsedirektoratet, 2009.

4. Fure B, Lauvrak V, Arentz-Hansen H, Skår Å, Ormstad SS, Vang VJ, Frønsdal KB. Metodevurderinger: Kunnskapsbasert beslutningsstøtte på overordnet nivå i helsetjenesten. Norsk Epidemiologi 2013; 23 (3): 165-169.

5. Mednytt. Vurdering av nye medisinske metoder [database]. Nasjonalt kunnskapssenter for helsetjenesten. www.mednytt.no (07.08.13).

6. Grade Working Group. www.gradeworkinggroup.org (07.08.13).

7. Den nasjonale databasen for mini-metodevurdering [database]. Nasjonalt kunnskapssenter for helsetjenesten. www.minimetodevurdering.no (07.08.13).

8. Adopting Hospital Based Health Technology Assessment. www.adhophta.eu (07.08.13). 